\title{
IAMJ
}

INTERNATIONAL

AYURVEDIC

MEDICAL JOURNAL

\section{MEDICAL MANAGEMENT OF TINEA INFECTION THROUGH SHODHANA AND SHAMANA - A CASE SERIES}

\author{
$\underline{\text { Asha A Bhat }}{ }^{1}$, Prashanth A S ${ }^{2}$
}

${ }^{1}$ Final Year PG Scholar, Department of Kayachikitsa

${ }^{2} \mathrm{MD}, \mathrm{PhD}$, Professor and HOD Department of Kayachikitsa

Ayurveda Mahavidyalaya Hubballi, Karnataka, India.

Corresponding Author:ashaabhat2504@gmail.com

\section{https://doi.org/10.46607/iamj1509092021}

(Published Online: September 2021)

Open Access

(C) International Ayurvedic Medical Journal, India 2021

Article Received: 31/08//2021 - Peer Reviewed: 06/09/2021 - Accepted for Publication: 07/09/2021

\section{Check for updates}

\section{ABSTRACT}

Skin is one of the most beautiful organs God has ever blessed to anyone. Everyone craves for beautiful skin and makes all possible efforts to make it glow. To achieve this, they are engaged in continuous use of creams, moisturizers and other cosmetic articles which lead to immediate or long-term skin issues. Itching being the predominant symptom of these cosmetic issues make people highly embarrassed in society. In Ayurveda, almost all skin conditions are explained under one umbrella called Kushta. It is broadly classified into Mahakushta and Kshudrakushtal ${ }^{l}$ Dadru Kushta one among the Kshudra Kushta is the most common skin condition accounts for $20 \%$ in all consultation in general practice ${ }^{2}$. North Karnataka is well known for its hot and humid conditions making its population at risk of many Tinea infections. Kandu, Raga and Atasi Pushpa Sankashavat Mandala are the cardinal features of Dadru ${ }^{3}$. In the present case study, 40 patients of Dadru Kushta were taken according to inclusion criteria. The combined effect of both Shodhana and Shamana was assessed.

Keywords: Dadru Kushta, Aupasargika, Anushangi, Wilcoxon Rank Sum Test 


\section{INTRODUCTION}

Dadru Kushta is a Kapha Pitta Pradhana Kushta which has been considered as one of the Mahakushta by Acharya Sushruta under the context of Aupasargika Roga $a^{4}$ and Vagbhata as Anushangi ${ }^{5}$ whereas Kshudra Kushta by Acharya Charaka which closely resembles with Tinea infection commonly called Ringworm infection. Worldwide 39\% and in India 5 out of 1000 people are suffering from Tinea infection. The main cause of this infection is Dermatophyte which spreads by contact because of improper lifestyle, uncleanliness of body, sharing clothes of others etc. The fungi often tend to linger on clothes, towels, surfaces and within brushes or combs. Dadruvyadhi is a commonly recurring skin disease and is Anushangi. Hence Shodhana and Shamana Chikitsa give a better result when compared to only Shamanoushadhis. Hence in the present study, an attempt was made to manage Dadru Kushta through Shodhana, Shamana and Bahirparimarjana Chikitsa in a single group of 40 patients through various observations and statistical methods.

\section{MATERIALS AND METHODS}

Aims and Objectives- To evaluate the combined effect of Snehapana, Virechana and Shamana in the management of Dadru Kushta

Centre of Study- Ayurveda Mahavidyalaya Hubballi (Karnataka)

\section{INCLUSION CRITERIA}

* Subjects with classical symptoms of Dadru as Twak Kandu, Raga, Pidaka and Mandala.

* Subjects of both genders, irrespective of socioeconomic status, belonging to the age group between 20- 60 years of age.

* Subjects fit for Snehapana and Virechana.

\section{EXCLUSION CRITERIA}

* Subjects suffering from any chronic illness, HIV/ HBsAg/VDRL/STDs and other metabolic disorders will be excluded.

* Pregnant and Lactating women

* Other skin conditions like Psoriasis, Urticaria, except fungal infections of the skin.

TABLE 1: ASSESSMENT CRITERIA

\begin{tabular}{|c|c|c|c|c|c|}
\hline $\begin{array}{l}\text { Sl. } \\
\text { No. }\end{array}$ & Parameter & Grade 0 & Grade 1 & Grade 2 & Grade 3 \\
\hline 1. & Kandu & No itching & $\begin{array}{l}\text { Mild Itching but not dis- } \\
\text { turbing normal activity }\end{array}$ & $\begin{array}{l}\text { Moderate itching dis- } \\
\text { turbing normal activity }\end{array}$ & $\begin{array}{l}\text { Itching present contin- } \\
\text { uously and even dis- } \\
\text { turbs the sleep }\end{array}$ \\
\hline 2. & Raga & Normal skin & $\begin{array}{l}\text { Light-Dark pink appear- } \\
\text { ance }\end{array}$ & Red appearance & $\begin{array}{l}\text { Deep Red to Purple } \\
\text { appearance }\end{array}$ \\
\hline 3. & Vaivarnyata & Normal skin color & Reddish discoloration & $\begin{array}{l}\text { Reddish Black discol- } \\
\text { oration }\end{array}$ & Blackish discoloration \\
\hline 4. & Size of lesion & Absence of lesion & $>0-10 \mathrm{cms}$ & $>10-20 \mathrm{~cm}$ & Above $20 \mathrm{~cm}$ \\
\hline 5. & No. of lesion & No lesion & 1 & 2 & 3 and $>3$ \\
\hline 6. & $\begin{array}{l}\text { Characteristics } \\
\text { of lesion }\end{array}$ & No lesion & Annular lesion & $\begin{array}{l}\text { Annular Erythematic } \\
\text { lesion }\end{array}$ & $\begin{array}{l}\text { Annular Erythematic } \\
\text { Plaques }\end{array}$ \\
\hline
\end{tabular}


TABLE 2: INTERVENTION OF THE STUDY

\begin{tabular}{|l|l|l|l|l|}
\hline Sl. no & Procedure & Dravya & Matra & Duration \\
\hline 1. & AmaPachana & $\begin{array}{l}\text { Ajamodadi choorna with } \\
\text { Ushnajala as Anupana }\end{array}$ & 5 gms twice daily Before food & $\begin{array}{l}\text { 3-5days/till } \\
\text { Lakshanas seen }\end{array}$ \\
\hline 2. & Sadyosnehapana & Patolady Ghrita & $\begin{array}{l}\text { Roga and Rogi balanusara and Ko- } \\
\text { shta and Agni (70-100ml) }\end{array}$ & $1-3$ days \\
\hline 3. & Sarvanga abhyanga & ChakramardaTaila & Quantity Sufficient & 1 day \\
\hline 4. & Virechana & Trivrut Lehya & $30-40$ gms & 1 day \\
\hline 5. & Shamanoushadhi & Dadrughna Kashaya & 30 ml twice a day Before Food & 45 days \\
\hline 6. & $\begin{array}{l}\text { Bahirparimarjana } \\
\text { chikitsa as Lepa }\end{array}$ & VidangadiLepa & Quantity Sufficient & 45 days \\
\hline
\end{tabular}

\section{RESULTS}

Wilcoxon Rank Sum Test was applied to see the significant change before and after treatment in the symptoms and other data.

There was a statistically highly significant difference on Kandu $(\mathrm{Z}=4.72$, $\mathrm{p}<0.001)$, Raga $(\mathrm{Z}=0.109, \mathrm{p}<0.001)$, Vaivarnyata $(\mathrm{Z}=0.80$, $\mathrm{p}<0.001)$, size of the lesion $(Z=3.99, \mathrm{p}<0.001)$, Number of the lesion $(\mathrm{Z}=3.77, \quad \mathrm{P}<0.001)$, characteristics of lesion $(\mathrm{Z}=4.23, \mathrm{P}<0.001)$ respectively.

\section{FOLLOW-UPS AND OUTCOME}

After completion of treatment, there was a marked improvement in symptoms like Kandu (Itching), $R a$ ga (Erythema), Utsanna Mandala (Lesions). There were no complications in any of the subjects during and after treatment. Follow up was done for 60 days. There was about $90 \%$ relief in the symptoms.

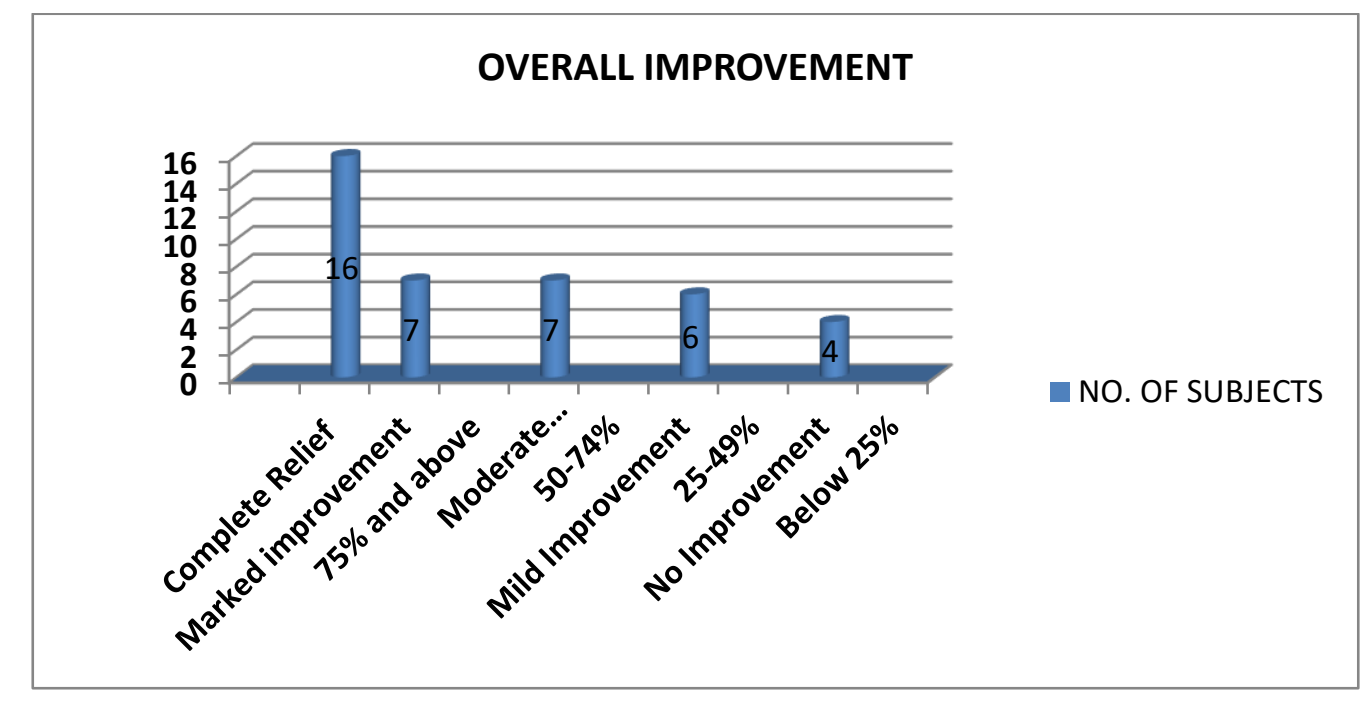

In this study out of 40 subjects of Dadru Kushta (Tinea), a total of 16 subjects had got complete relief. 7 subjects had marked improvement, 7 subjects in a group had moderate improvement, 6 subjects had mild improvement and the remaining 4 subjects had no improvement after the treatment. 
Figure 1: KOH MOUNT

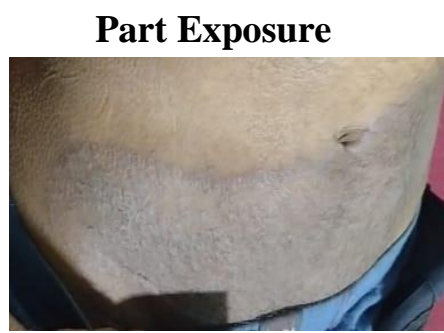
Skin Scrapings

Collection of Sample

labeling the sample

The sample is mixed to $0.5 \mathrm{ml} 20 \% \mathrm{KOH}$ Solution

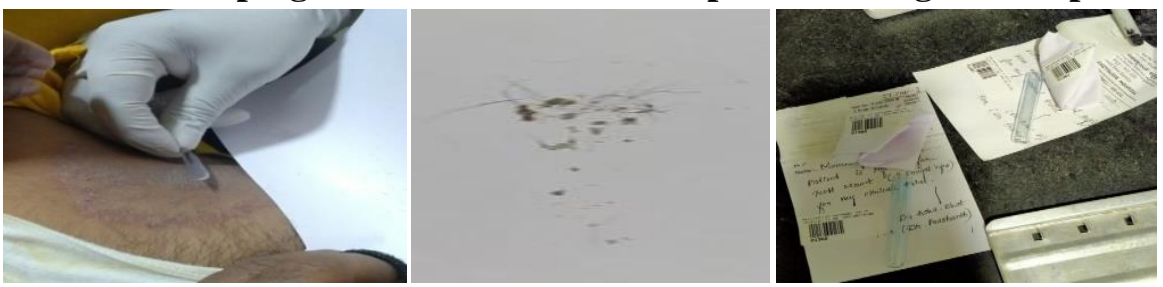

Slide mounting
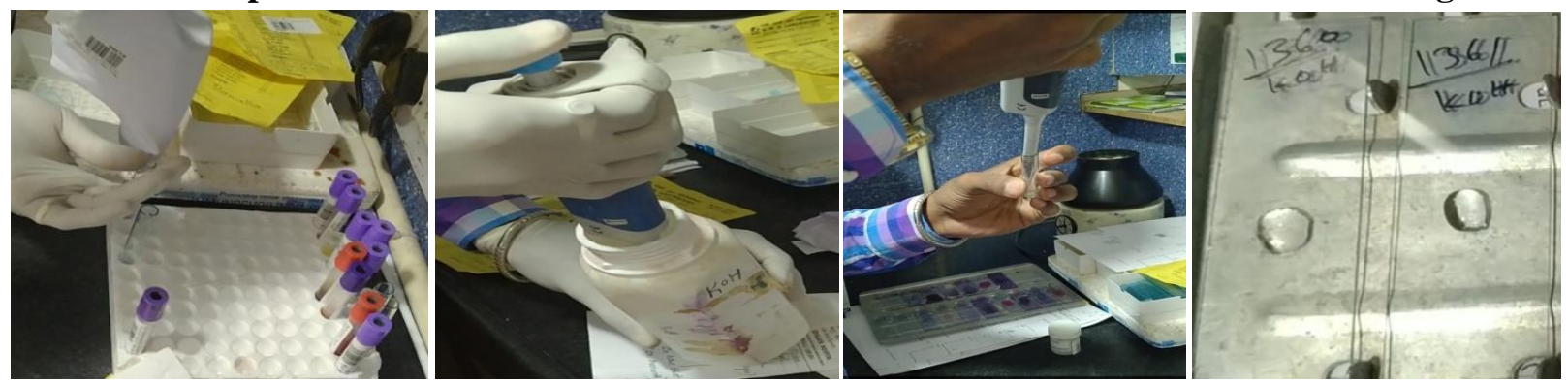

SAMPLE WITH POSITIVE FUNGAL ELEMENTS
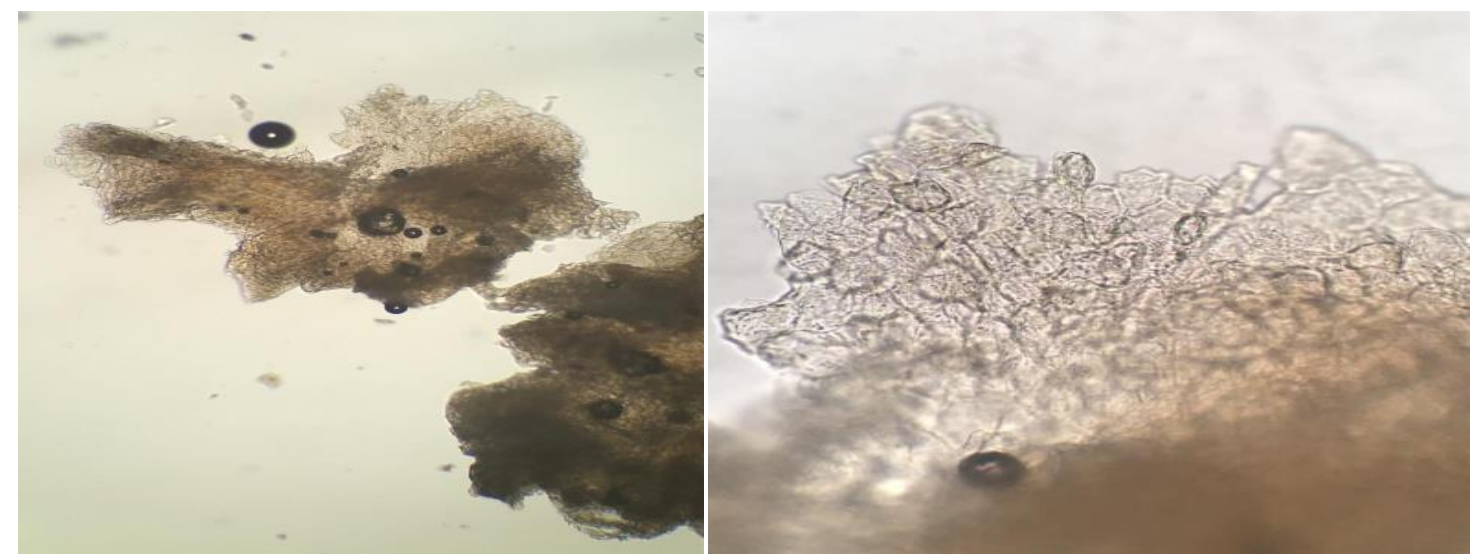

FIGURE 2: PHOTOGRAPHY OF SUBJECTS OF PRESENT CLINICAL STUDY BEFORE TREATMENT AFTER TREATMENT BEFORE TREATMENT AFTER TREATMENT
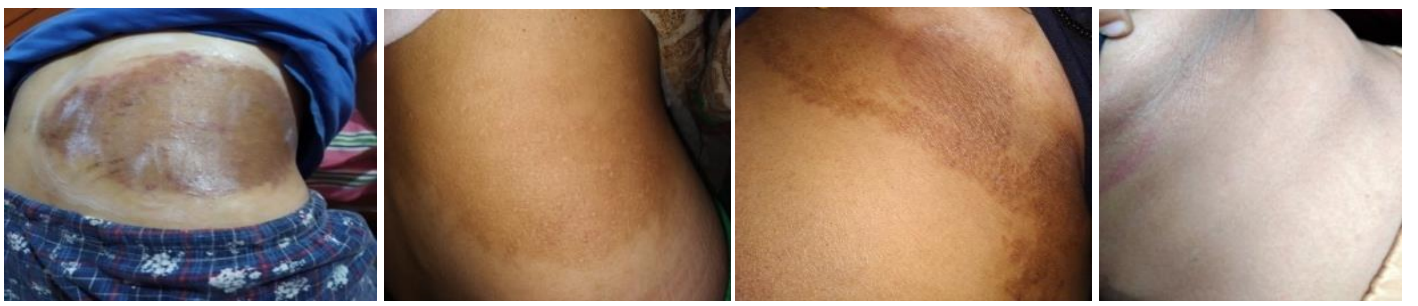


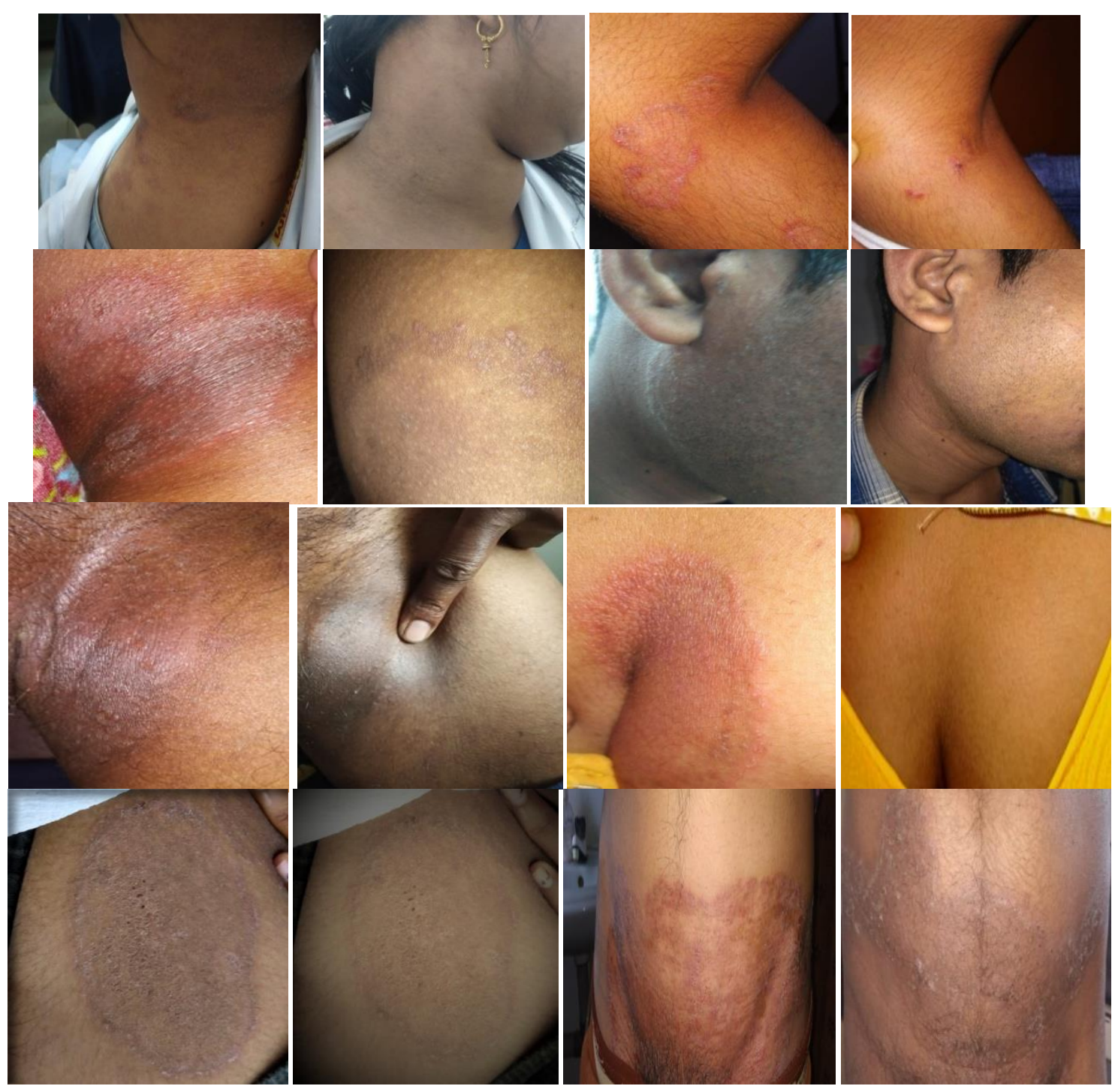

\section{DISCUSSION}

Cosmetic problems are the burning issues in today's time and a lot of attention has been made towards such problems in the past few years. Fungal infections are very common among day-to-day OPD practices. North Karnataka has a hot and humid climate which is very favorable for this infection and hence the study was undertaken.

Ajamodadi Churna was used for Amapachana which is best Kaphahara, Kandughna and Krimighna and Amapachana. Sadyosnehapana was done for 1-3 days according to Agni and Koshta of a person with Patoladya Ghrita which mainly contains Patola, Nimba, Vasa, Draksha, Triphala etc Dravyas which are mainly Tikta Dravyas, Ushna Veerya; indicated in
Kushta, Timira, Vruna. So, the intensity of choosing this Ghrita as Snehapana before Virechana Karma in Dadru Samprapti is mainly due to Kapha Pitta Dosha Dushti and Rakta dushti. Chakramarda Taila is the best Krimighna and proved as best Dadrughni (antifungal) was used for Abhyangartha. VirechanaTrivrut is mainly having Tikta, Katu Rasa, Ushna Veerya, Kaphapittahara and Kushtaghna property. It is a Sukha Virechaka. Katu Rasa "Margan Vivrunoti" means it dilates the Srotas and thus acts at the cellular level and stops the uncontrolled production of cells which cause Utsanna Mandala. By its Srotoshodhana property, it acts on minute channels and does Twak Prasadana. Dadrughna Kashaya Pana-Dadrughna Kashaya contains Aragwadha, Nimba, Kutaja, Mus- 
ta, Guduchi, Karanja, Haridra, Maricha, Vidanga, Bhunimba, Amalaki, Khadira and all were taken in equal proportions. Most of the ingredients are having Kushtaghna, Kandughna, Krimighna, Kaphapittahara, Tikta Rasa Pradhana, Ushna Veerya, Katu Vipa$k a$ which helps in breaking Samprapti of Dadru.

Vidangadi Lepa for external Application-It is a kind of Pradeha because most of the drugs are having Ushna Veerya. Lepa imparts Ushnata in the body. The ingredients like Vidanga, Chakramarda, Sarshapa are best Kandughna and Krimighna. Haridra is Varna Prasadana. This helps in normalizing the skin colour.

\section{Discussion on Observations}

In the present clinical trial, most of the subjects were students and were hostilities hence there were more chances of transmission of fungal spores and were from urban areas hence use of washing machines for clothes there are more chances of mixing contaminated clothes with a healthy one. Most of them had a family history this may be due to transmission and not merely a genetic predisposition. Most of them were having a mixed diet which is Abhishyandi leading to Mandagni, and continuous usage leads to Raktadushti. Junk foods are very common. Most of them rely on them even for Lunch and Dinner which hampers Koshta and leads to Malabaddhata and leads to Ama. The inbuilt toxins do Srotodushti and Kushta utpatti. Ratrijagarana is one common thing among students this also hampers the Dosha which does Agni Dushti.

\section{Discussion on Results}

Kandu occur either due to excessive accumulation of dust, sweat, Rakta Dushti and Kapha Vruddhi. The line of treatment is to correct the Rakta Dushti, decrease the Kapha Dosha and accumulation of dust, and sweat on the skin. Drugs of Dadrughna Kashaya are having Kaphaghna, Kandughna, Krimighna, Raktashodhaka and Raktaprasadaka properties. Here Vidangadi Lepa on external application helps in the reduction of Kandu.

Raga and Vaivarnyata-Raga is a Prakopa Lakshana of Pitta and Vata Dosha; Rakta dushti and Pitta vikruti leads to Vaivarnyata. Lepa helps in reducing
Pitta and Vata Doshas. Most of the drugs used in Shamana are having Rakta Shodhaka, Rakta prasadana and Varnya property and Lepa mainly act locally in correcting Bhrajaka Pitta hence normalizing the color of skin.

Size, Number of lesion and characteristics of lesion-Spreading of disease or extended area of involvement is due to Vata Prakopa as well as Rasa and Rakta Dushti. These entities reach every part of the body due to their Chala, Sara, Sukshma Guna. Trivrut is mainly having Kaphapittahara action and thus helps in the reduction of size and number of the lesion. Due to increased Rukshata there will be an accumulation of Kleda and Mala in Twak it results in thickening of the skin. Twak being the Sthana of Vata, Prakupita Vata causes overproduction of skin. Thickening of skin is due to increased production of cells especially Keratinocytes. Lekhaniya property of Musta and Karanja, Twachya property of Haridra, Yashti and Chandana helps in the reduction of inflammation and thickening of the skin. Triphala, Musta, Bhunimba. Katuki are Srotoshodhaka and are Pittahara.

\section{CONCLUSION}

Dadru is a Kapha Pitta Pradhana Rasa and Rakta Dhatu Pradoshaja Vikara. Being Aupasargika Vyad$h i$ it is highly contagious hence a proper Pathyapathya and lifestyle modifications are the point of concern along with the main treatment course. In the present study, the combined effect of Sneha Virechana and Shamana gave a highly significant result in symptoms of Kandu, Raga and Mandala during as well as follow up of the treatment.

\section{REFERENCES}

1. Editor and Translator Vaidya Harish Chandra Singh Kushwaha. Agnivesha Charakasamhita, Chakrapanidattas Ayurveda Dipika Ayushi Hindi Commentary. The first part, Nidanasthana, 5th Chapter Kushtanidanam Adhyaya Verse number 4, Chaukhambha Orientalia, Varanasi. Edition Reprint 2012, page number556.

2. Edited by Anthony S. Faucy, Eugene, Stephen Harrisons Principle of Internal Medicine 17th Edition Vol- 
ume 1 Section 9 Alterations in the Skin, and Chapter 52 Approaches to the patient with Skin Disorders page number-318.

3. Editor Vaidya Jadavji Trikamji and Narayan Ram Acharya Sushruta Samhita of Sushruta, Nibandha Sangraha commentary of Shri Dakhanacharya and Nyaya Chandrika of Gayadas Acharya on Nidanasthana. Chapter 5 Kushtanidana Adhyaya Verse number-8, Chaukhambha Orientalia, Varanasi Edition Reprint 2014, Page number- 284

4. Editor Vaidya Jadavji Trikamji and Narayan Ram Acharya Sushruta Samhita of Sushruta, Nibandha Sangraha commentary of Shri Dakhanacharya and Nyaya Chandrika of Gayadas Acharya on Nidanasthana. Chapter 5 Kushtanidana Adhyaya Verse number-34, Chaukhambha Orientalia, Varanasi Edition Reprint 2014, Page number- 289

5. Editor Pt. HariSadashiva Paradakara Acharya Vagbhata Ashtanga Hrudaya with the commentaries of Sarvanga Sundari of Arunadatta and Ayurveda Rasayana of Hemadri. Nidanasthana, Chapter number 14, Kushtashwitrakriminidana Adhyaya Verse no-, Chaukhambha Samskrita samsthana, Varanasi. Edition Reprint 2012, Page number-526.

\section{Source of Support: Nil \\ Conflict of Interest: None Declared}

How to cite this URL: Asha A Bhat: Medical Management of Tinea Infection through Shodhana and Shamana - A Case Series. International Ayurvedic Medical Journal \{online\} 2021 \{cited September 2021\} Available from: http://www.iamj.in/posts/images/upload/2029_2036.pdf 